\title{
人工塞栓術直後に腫瘍出血をきたした随膜腫の１例
}

\author{
渡辺 一良·松村 憲一・松田 昌之・半田 讓二
}

\section{Meningioma with Intratumoral and Subdural Hemorrhage as an Immediate Complication of Therapeutic Embolization}

Case Report

\author{
Kazuyoshi Watanabe, Ken-ichi Matsumura, Masayuki Matsuda \\ and Jyoji HANDA \\ Department of Neurosurgery, Shiga University of Medical Science, Ohtsu
}

\begin{abstract}
A 63-year-old female with a large meningioma of the middle cranial fossa was admitted. The tumor was fed mainly by the hypertrophied middle meningeal artery. Immediately following a seemingly successful embolization of that artery with gelfoam powder, consciousness of the patient rapidly declined and anisocoria and deccrebrate posturing developed. An intratumoral massive hemorrhage ruptured into and extended widely in the subdural space was confirmed by computed tomography scan. The hematoma was evacuated and the tumor was radically removed by emergency craniotomy, and the patient recovered.

Therapeutic embolization for meningiomas and other highly vascular intracranial tumors has been established as a useful and relatively safe adjunctive preoperative measure, and an intratumoral massive hemorrhage in the period immediately following this procedure has seldom been reported in the literature. However, the present case shows that it is apparently a potential complication of this procedure. The possible mechanisms of an intratumoral hemorrhage following therapeutic embolization of the feeding arteries are briefly discussed.
\end{abstract}

Key words: meningioma, intracranial hemorrhage, therapeutic embolization, gelfoam powder, surgical removal

\section{I はじめに}

頭蓋内腫瘍や血管奇形などに対して，手術時の出血量を 軽隇させる目的で，あるいは手術的治療が困難な場合の根 治療法とLて，人工的塞栓術 (therapeutic embolization) 用いられる。なかでも，䯣膜腫は外頸動脈枝より栄着され ることが多いため，しばしば人工塞栓術の良い適応上な

る.今回我々は，人工塞栓術を施行した直捘に，腫瘍内打 よび硬膜下出血が生じた㭪膜腫の症例を程験した。これま
でにも人工寒栓術の合併症として腫瘍内出血は報告されて いる5,10が，いずれも出血は比較的軽微であり，また本症

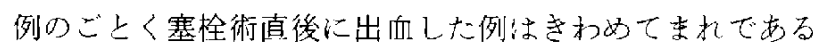
ため，若干の文献的考察を加えて報告する。

\section{II 症例}

<患者〉63才，女性

主訴：頭痛, 記銘力減退

既往歴：1982年頃，嘔気在伴う左側頭部痛のため5日

Address reprint requests to: K. Watanabe, M.D., Department of Ncurosurgery, Shiga University of Medical Science, Seta-tsukinowa-cho, Ohtsu 520-21

受稿 1985年7月12日 受理 1986年6月11日
} 
閒，さらにその3力月後にも同様の症状で 3 日間療盖した ことがあるが，小五れる神経学的脱落症状なく治㾍した。

現病歴：1984年 8 月搷より自热性欠如, 意欲減退, 発語 の減少に気付き，1985年 1 月頃より記銘力障害扰よび前傾 小刻み歩行が出現した。同年 4 H，CTで異常を指摘され たため入院した。

入院時所見：頭悀，嘔気などはなく，神経学的には意識 清明て，左側眼底に軽度のうの血乳頭を認めるも視力心正 常であった，左動眼神経代全麻婥在認好たか，錐体路徽候 はなかったその他，無表情，無気小，記銘力低下があり

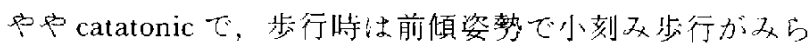

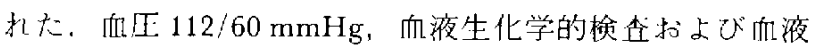
凝固能検奋で当異常を認めなか的た。

入院後経過：頭部 CT:て, 左蝶形骨縁から錐体前縁に

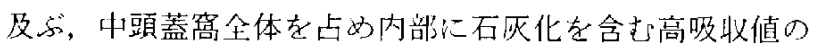
腫瘤を認め，中等度の正中偏位省伴っていた，腫瘍汢，造 影剂静注により均一に増强された(Fig. 1)。5月1日， Seldinger 法に上り Newton 7636 カテーテルを用いて左内 頸動脈，椎骨動脈，および外頸動脈撮影を行った。こ 間，血厈は 120〜140/80〜90 mmHgで安定し，意識扣上 び神経学的所見に変化はみられなかった，外頸動脈撮影で は主として中硬膜動脈を起源となるきわわて高度の腫堭血 管像を認め，静脈相末期まで均質な陰影上して残存してお り，髄膜腫に典型的な像を小していた(Fig. 2A)。そこで， 引き続きカテーテル先端を左外頸動脈の分岐部上り約 5

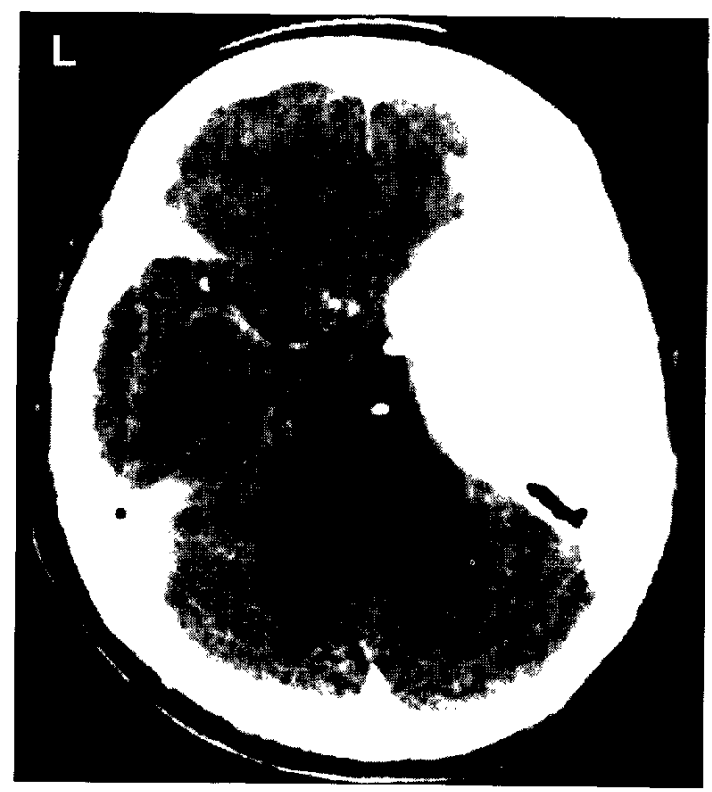

Fig. 1 Enhanced computed tomography (CT) scan, showing a large middle fossa meningioma.
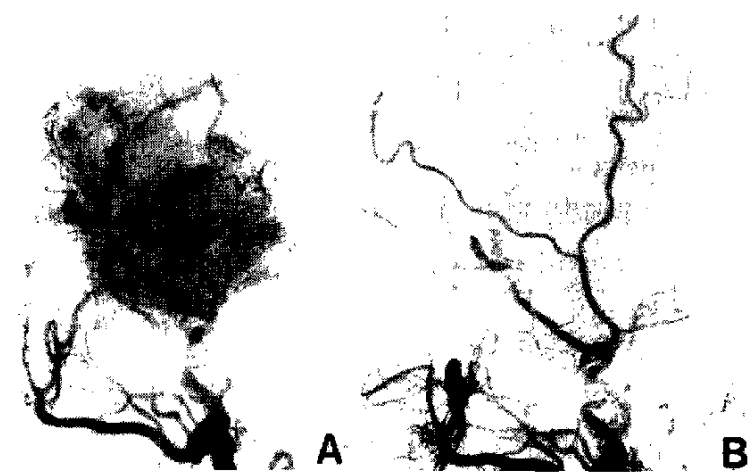

Fig. 2 Selective left external carotid angiograms. A: Before embolization. Note prominent tumor vessels. B: After embolization. The middle meningeal artery is occluded and the tumor stain is barely visible.

$\mathrm{cm}$ 末梢に置さ，主要栄盖血管である左，中硬膜動脈が硬膜 を呀通寸る部分から約 $2 \mathrm{~mm}$ 枺梢で描出されず腫瘍陰影も 認められなくなるまで，造影剤に混じた gelfoam powder を数回に分けて透視下で観察しながら注入した（Fig. 2B）。 この直後に，患者は嘔吐をきたをとともに昏迷状態となっ た。ただんがーテルを抜去し，穿刺部を压迫している 5ちに意識状態はさらに悪化し，右片麻疸が出現した。即 効型ステロイド剤を静注のトCT室に搬入した際の血业は $170 / 100 \mathrm{mmHg}$ ，呼吸仕不整で浅表性であった，人工塞栓 術淩のCT て腫瘍内出血之硬膜下血腫, さらに占拠性効果

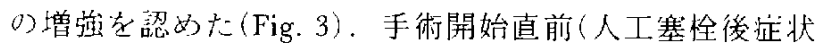
覀化を認めてから約 1 時間後)には半昏睡上なり，左瞳孔 は散大, 対光皮射讨遅延し, 痛刺激で右除脳姿勢を古し t:

手術所見：左前頭側頭開頙を行らと，硬膜队王は著明に 六進し，術野全域に硬膜下血腫が透見された。側頭骨鱗部 と蝶形骨縁を削除する際，中頭蓋窝先端で暗赤色心腫瘍が 硬膜および骨を穿通して pterygoid fossa に進展しているの が誌められた，硬膜を切開し厚さ約 $5 \mathrm{~mm}$ の硬膜下血腫を 除去すると，脳実啠外腫瘍が溯頭葉・側頭葉を举上して中 頭蓋窩を洲たし，一部蝶形骨縁を越えて前頭蓋登に達する のが認められた，腫瘍は暗赤色で弾性軟，血管に富み易出

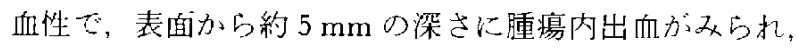
これが穿破して硬膜下血腫に連なるのが涩めちれた，CU-

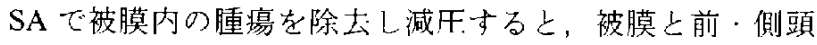
葉, 左内頸 · 中大脳・後交通各動脈, 左第 II · III脸神経上 の剥離は容易で，pterygoid fossaへの進展を含め腫瘍を全 剔出した。硬膜への付着部は明らかでなかったが，少なく とも蝶形骨縁ではなく，おそらく pterygoid fossa 一進展し ていた中頭蓋窩先端の大翼中央部付近と思的れた。 

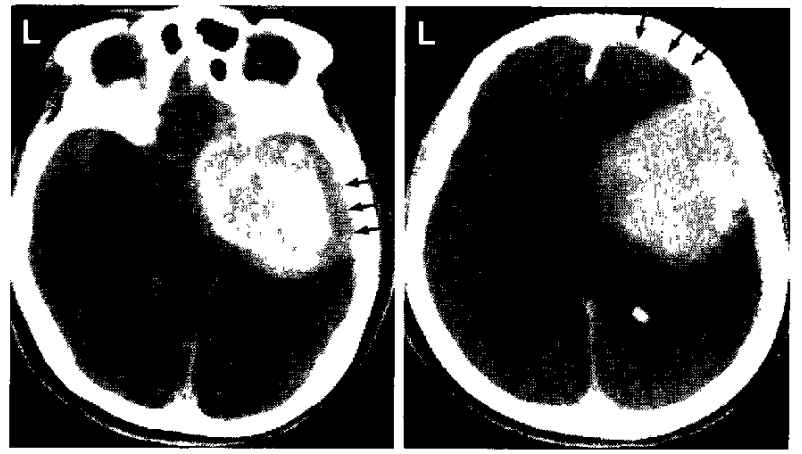

Fig 3 CT scan obtaıned immediately after embolization The tumor is enhanced by contrast medium used at the preceding angıography Lower window level and higher window width settings are used to show the hemorrhage to better advantage (arrows)

組織学的には, 大型細胞の whorl formation $と$ bipolar cell streamを認め，多型性は低く，transitional meningioma と訬断された(Fig. 4).

術媵経過：術後間もなく意識障害および右片麻瘦は改善 したが，左眼失明が明らかとなった。これは，眼底検查に より左網膜中心動脈の白色構造物による閉塞と網膜虚血の 像が認めら机たことから，中心動脈閉塞によるものと判明 し，人工塞拴の合併症と考光られた，術後の CTでは腫瘍 は全剔出されて扔り，頭蓋形成術を施行したのb左眼失明 学残して退院した。

\section{III 考察}

頭蓋内疾患に対する人工塞栓術は，脳動静脈奇形や雭性 腫瘍などにおいて手術に代わる力法として行われることが ある2,3,12-15)が，䯣膜腫などの血管に富又手術時大量出血 が予想される腫瘍に対しては，手術を前提とし術中出血の 減少を目的として施行されることが多(5,10,17). Kepes ${ }^{6 !}$ ， Modestiらが指摘しているように，髄膜腫は頭蓋内监管 性病変上上く似た症状を呈して発症するこ之も多 $\langle 3,4,8-11,13,15\rangle$ ，また多型件.腤芽腫，下垂体腺腫，転移性腫 瘍任どではない16,18ににしても，自然経過として出血するこ とも稀有と法言之ない。さらに尾藤ら”は，髄膜腫は脳 内・硬膜下・クモ膜下出血など䫑蓋内出血の各型を合併し らるばかりでなく，静脈洞や大血管老き込み，またはこ れらを厈排して頭蓋们压元進症状や脳虚血性变化を引き起 こし，急性発症ないし増悪しらると報告している，しかし 本症例では，その時間的関係からこの腫瘍出血が偶発性の ものと考えるのは困難です，人上塞栓術により引き起こ されたもの上考光る。

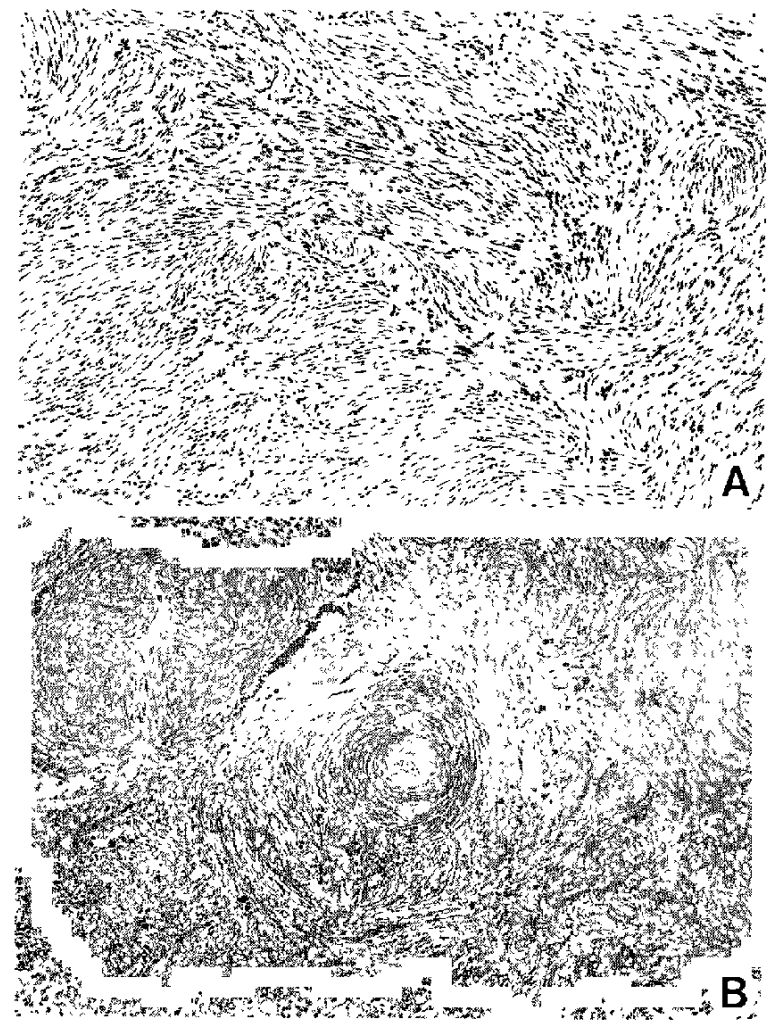

Fig. 4 Photomicrographs of the surgical specimen. HE stain, $\times 40$ A. Sheets of whorls of polygonal large cells and streams of bipolar cells are seen. Transitional menıngioma. B- Intraparenchymal hemorrhage surrounding the arterioles of normal appearance

人工塞栓術の合併症としては，直徭に生ずるものとして 前頭部・下䪽部・側頭部などの疼痛, 内頸動脈に塞栓物質 が流入することによる脳梗塞などが，また数日を経てから 明らかになるものとして皮膚創偒の癒合不全，頭蓋内出 血，肺塞栓などがしばしば報告されている3,5,8,10,12,13,15;。 また，腫瘍に対する人工塞栓術ののちに，腫瘍の虚血や壊 死により占拠性効果の増强をさたすことがあることすよく 知られているが，本症例のごとく人工塞栓術直後に頭蓋内 出血が生じ急速に悪化した報告は脳動静脈奇形で数例 ${ }^{3,8}$ を認めるにすぎ゙，それ以外に頭蓋内腫瘍例ではほとんど 報告がない，人工塞栓術後に腫瘍内出血の生ずる機序とし ては，(1)いたん閉塞した栄盖血管の再開通による出血性 梗塞の場合，(2)複数の栄養血管を有する病変でそのいずれ かが閉塞されずに残存し，これにかかる静水下(血圧)か上 昇して動脈側で血管の破諚をきたす場合，(3)塞栓物質が栄 昱動脈を通り過さて静脈部分を閉塞したため出血する場 合，(4)腫痬内の出血しやすい component生方方 angioma, aneurysm，不完全な血管壁を有する新生血管な 


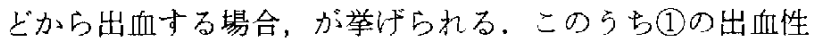
梗塞は, 栄養動脈閉塞に上り腫瘍括よび腫瘍内血管が壊死 に陥るだけの時間が必要であり，少なくとも症状発現まで に数時間を要するとされる. 本症例のごとく, 塞栓術後数 分間で意識レベルの低下，苟るいは嘔吐などの頭蓋内出血 に伴う庭状を呈した場合には，(2)〜(4)のいずれかまたは々 の組公合せが考兄やすい，本症例では出血部分の病理標本 で，細動脈を中心としこれを取り巻くよらに㼛漫性の出血 所見が認められたが，多数の標本でも梗塞所見法認められ なかった，本症例の場合，腫瘍は外頸動脈起源の中硬膜動 脈の活かにも内頸動脈から眼動脈括上び添腺動脈，また meningohypophyseal trunkより天幕動脈の分枝, さらに中 大脳動脈の分枝などにより栄養されて㧍り，このらち主た る中硬膜動脈が閉塞しても他のルートによる血流は保たれ る。また，使用した gelfoam powderは粉末状で細かいた め, これが静脈性部分を一次的閉塞し，少なくとも内頸 動脈からの動脈血流入はあまり減少しないため, 腫痬血管 の内圧が充進して破糘し出血したことが考えられる。いす゚ れにしても，本症例は，良性腫瘍に対する人工塞栓術の場 合でも頭蓋内出血の可能性を常に念頭に置き，祭急手術で 対処できるよう準備を整えたトで行らべきで满ることを示 唆している。また，睡瘍摘出術は一般に人工塞栓術後でき るだけ早期に計画すべきで满ると思和れる5,10!。なお，本 症例でみられた患側の網膜中心動脈閉塞症は，(1)塞栓物質 が内頸動脈へ々逆流して眼動脈を閉塞した，(2)睡瘍内出血 に上り内頸動脈が急激に挙上伸展し, 眼動脈起始部に狭窄 ないしねじれが生じた，(3外頸動脈一買動脈一涙腺動脈一 眼動脈のルートを経て gelfoamにより眼動脈が閉塞され た，などの理由が考光られる。そのいずれが正しいが汢洪 定しがたいが，人工塞栓術後の選択的外頸動脈撮影で仍の ルートを経て内頸動脈が描出されていることから，最後の 推論电否定し克ない。

\section{N 結 語}

人工塞栓術直後に腫瘍内出血をきたし，緊急手術汇より 救命し壳た 1 例を報告し, 出血の機序について考察を加兑 た．髄膜腫などの比較的腫瘍内出血がまれである腫瘍に対 して人工塞栓術を施行する場合でも，頭蓋内出血などの緊 急事態に対処できるよら心がけるべきであることを強調し た。

\section{文献}

1）尾藤昭二，榊 三郎：中大脳動脈閉塞に上って急速に症状 の発現をみた中頭蓋窝㖪膜腫の一例。脳と神 23：953-957，
1971

2) Budny JL, Glasauer FE, Sil R: Rapid recurrence of meningioma causing intracerebral hemorrhage. Surg Neurol 8: 323-325, 1977

3) Debrun G, Vinuera F, Fox A, Drake CG: Embolization of cerebral arteriovenous malformations with bucrylate. $J$ Neurosurg 56: 615-627, 1982

4) Glass B, Abbot KH: Subarachnoid haemorrhage consequent to intracranial tumors. Arch Neurol Psychiat 73: 369-379, 1955

5) 君藤替介, 横山元晴, 今村均, 吉田誠一, 椠山和雄：外 頸動脈領域に捛ける embolization の経験. 脳神外科 8: 1145 1153,1980

6) Kepes JJ: Meningiomas: Biology, Pathology and Differential Diagnosis. New York, Masson, 1982, pp 32-33

7) Modesti LM, Binet EF, Collins GH: Meningiomas causing spontaneous intracranial hematomas. $J$ Neurosurg 45: 437-441, 1976

8) Pevsner PH, Doppman JL: Therapeutic embolization with a microballoon catheter system. Amer J Roentgen 134: 949-958, 1980

9) Rosenberg GA, Herz DA, Leeds N, Strully K: Meckel's cave meningiomas with subarachnoid hemorrhage. Surg Neurol 3: 333336,1975

10）志賀逸太，柳下 章，大内敏安，岩田隆信，广谷重雄：頭 蓋内䯣膜腫への応用一人工.塞栓術の臨床応用一。臨放線 26 : $7-13,1981$

11) Smith VR, Stein PS, MacCarty CS: Subarachnoid hemorrhage due to lateral ventricular meningiomas. Surg Neurol 4: 241-243, 1975

12) Suzuki J, Komatsu S: New embolization method using estrogen for dural arteriovenous malformation and meningioma. Surg Neurol 16: 438-442, 1981

13) Wallace $S$, Charnsangavej $C$, Carrasco H, Bechtel W: Infusion-embolization. Cancer 54: 2751-2765, 1984

14) Walsh JW, Winston $K R$, Smith $T$ : Meningioma with subdural hematoma. Surg Neurol 8: 293-295, 1977

15) Whittle IR, Johnston IH, Besser M, Lamond TS, Silva M: Experience with bucrylate (isobutyl-2-cyanoacrylate) embolization of cerebral arteriovenous malformations during surgery. Surg Neurol 19: 442-449, 1983

16) Yasargil $\mathrm{MG}$, So $\mathrm{SC}$ : Cerebellopontine angle meningioma presenting as subarachnoid haemorrhage. Surg Neurol 6: 3-6, 1976

17) 吉田一成, 戸谷重雄，高宮至昭，村上秀樹，河瀬 斌，志 賀冕夫：頭蓋内髄膜腫に对する術前栄養血管塞性術. Neurol Med Chir (Tokyo) 25: 471-478, 1985

18) Zimmerman RA, Bilaniuk LT: Computed tomography of acute intratumoral hemorrhage. Radiology 135: 355-359, 1980

〔別刷請求先：干520-21 大津市瀬田月輪町，滋賀医科大学脳神 経外科, 渡辽一良] 